\title{
Institutional life within an entrepreneurial region
}

\author{
Nichola J. Lowe ${ }^{1}$ (D) | Maryann P. Feldman ${ }^{2}$
}

${ }^{1}$ Department of City and Regional Planning, University of North Carolina, Chapel Hill

${ }^{2}$ Department of Public Policy, Department of City and Regional Planning, University of North Carolina, Chapel Hill

\section{Correspondence}

Nichola J. Lowe, Department of City and Regional Planning, University of North Carolina, Chapel Hill, Chapel Hill, NC 27599, USA.

Email: nlowe@unc.edu

\begin{abstract}
Institutions are often regarded as static and unchanging, portrayed as constraints on innovation, entrepreneurship, and regional economic change. We propose an alternative perspective in order to understand how entrepreneurs experience and engage with institutions in ways that shape and help advance their collective interests. Motivated by our own research on regional entrepreneurial development, we theorize institutions as lived and interpreted experiences. We present institutional change as a creative and experimental response to emergent or competing logics. This conception of institutions has implications for how we theorize about economic transformation, recognizing that processes of institutional change are set in motion by endogenous attempts by economic actors to make sense of and act upon contradictory aspects of their varied institutional lives.
\end{abstract}

\section{KEYWORDS}

economic geography, entrepreneurial ecosystem, innovation, institutional change, institutions

\section{1 | INTRODUCTION}

Entrepreneurs are an especially admired group of economic actors, praised widely by scholars and practitioners alike for their willingness to take on considerable personal and financial risk in an effort to produce innovative goods and services. Yet when it comes to institutions, entrepreneurs are often presented as incredibly unentrepreneurial. Many scholars, including economic geographers, present institutions as either fixed, ordering structures, or as deeply internalized norms and taken-for-granted routines that limit human action or agency. Published entrepreneurial biographies offer an alternative perspective by providing rich inspiring narratives that speak to the creative attributes and actions of individual entrepreneurs or entrepreneurial teams. But in these accounts, questions of institutional context and influence are side stepped altogether suggesting room for additional theorizing. Correcting this oversight may not be enough, however, if our disciplinary response continues to obscure the contribution of entrepreneurs to institutional change and experimentation. What is needed is a better understanding of how entrepreneurs experience and engage with institutions in ways that help formulate and refine their collective interests.

We address this gap by theorizing that processes of regional economic transformation are set in motion by endogenous attempts by economic actors, in this case entrepreneurs, to make sense of institutions in the face of 
contradictions and constraints weighed against unlimited possibilities and demands. Upon closer examination, entrepreneurs view institutions as one of many malleable resources useful in shaping opportunity, mitigating risk and moving a nascent idea forward (Feldman \& Francis, 2002; Feldman, Francis, \& Bercovitz, 2005). In this regard, institutions are not just constitutive of entrepreneurial action. They are lived experiences and as such, institutions change not just because of an exogenous force or external shock, but because they are also reinterpreted and acted upon by those experiencing and living through them (Sine \& David, 2010). Defining institutions as lived experiences allows us to better understand cases in which entrepreneurial opportunities are strengthened when actors within an entrepreneurial community build political power through and within their affiliated institutions. With these analytical steps, economic geography can better capture the concurrent and intersecting institutional experiences and interpretations of entrepreneurs. Further scholarship in this area has the potential to facilitate additional rounds of institution building by inspiring future collective action and political participation.

Using the concept of an entrepreneurial ecosystem as a point of departure, we first turn to the treatment of institutions within economic geography. We then combine insights from political science and sociology to make a case for institutions as lived experiences and with institutional change set in motion by endogenous attempts by economic actors to make sense of and act upon contradictory aspects of their varied institutional lives. We conclude by offering an illustrative example from our ongoing research on entrepreneurial development, using it to motivate appreciative theorizing (Nelson, 1995). We share our empirical results to contribute methodological lessons but also to demonstrate the contribution of institutional life to regional entrepreneurial identify and community-building through processes of collective reinterpretation.

\section{AN INQUISITIVE AND INTERPRETATIVE AGENT}

Ecosystem is the word du jour in studies of regional entrepreneurship (Auerswald, 2015; Bell-Masterson \& Stangler, 2015; Mack \& Mayer, 2015). Defined in terms familiar to economic geographers, ecosystems are "a set of interconnected entrepreneurial actors, institutions, entrepreneurial organizations and entrepreneurial processes which formally and informally coalesce to connect, mediate and govern the performance within the entrepreneurial environment" (Mason \& Brown, 2014: 5). It is not surprising then that economic geographers are helping to ground this emergent concept, drawing theoretical and empirical connections to well-established areas of research on industrial clusters and regional innovation systems (Stam, 2015). As with that prior scholarship (Amin \& Thrift, 1995; Feldman \& Braunerhjelm, 2006; Gertler, 2003; Lowe, 2009; Malecki, 2009), ecosystems research recognizes that vibrant regional economies, including those favorable to new firm formation, are the product of interactions and interdependencies between economic actors, establishments, and institutions (Spigel, 2015). Similarly, ecosystems are not simply a reflection of existing economic transactions but rather stem from regionally specific "cultural outlooks, social networks ... and active economic policies" (Spigel, 2015: 1) and where sustained ecosystem success depends on more than profitable firms. It involves forward-thinking actions designed to extend current and future entrepreneurial opportunities (Motoyama \& Knowlton, 2016).

Still, the ecosystem concept offers much more than an application of existing theory to an economic subgroup, the entrepreneur. It provides an opening for economic geography to critically evaluate the role of entrepreneurs in relation to their surrounding institutional environments. We argue a useful starting place involves looking beyond established dichotomies that treat institutions as either formal or informal to consider the fluid boundaries that lie between.

Formal institutions are defined as "the rules of the game in a society; more formally the humanly devised constraints that shape human interaction" (North, 1990:477) and display a variety of forms, including "universal and transferable rules ... constitutions, laws, charters, by-laws and regulations, as well as elements such as rule of law and property rights and contact and competition monitoring systems" (Rodríguez-Pose, 2013: 1083). In contrast, informal institutions are defined as "norms, traditions and social conventions, interpersonal contacts, relationships 
and informal networks" (Rodríguez-Pose \& Storper, 2006:1). By drawing out this distinction, economic geographers challenge a common assumption in mainstream economics that only formal institutions matter for economic development, pointing instead to the essential role that informal institutions play in facilitating coordination, trust-building, and knowledge-sharing among economic actors and enterprises.

Recognizing this difference, some geographers have even proposed narrowing the definition of institutions to only those involving informal practices and shared social customs and traditions. Bathelt and Gluckler (2013) take this logic furthest, arguing that formal rules and regulations should not be considered institutions until they are internalized as established practices. They argue that "it is necessary to distinguish, on the one hand, between ... rules as prescriptions of legitimate or even legal behaviour, and, on the other hand, the resulting stabilized interaction practices," stressing that the latter, as stabilized practices are "the institutions that resulted from the new regulations" (Bathelt \& Gluckler, 2013:345). Emphasizing this distinction, they also claim that "rules and laws can be meaningless if common practices disregard or deviate from them without identifiable sanctions" (Bathelt \& Gluckler, 2013:346).

By elevating the importance of informal institutions, scholars of economic geography move the lens beyond efficiency-enhancing institutions-the main focus for mainstream economists-thus opening the possibility for studying regional institutional variation. Rodríguez-Pose (2013), for example, distinguishes between the institutional environment, which shapes the unique character of any place, versus the institutional arrangements, which represent barriers for the efficacy of other factors. In this regard, geographers also make a strong case for shifting the analysis away from traditional economic drivers, such as capital accumulation, towards context-specific and mediating institutional influences that are themselves socially and regionally constructed (Chang, 2003; Feldman \& Braunerhjelm, 2006; Gertler, 2003).

We see an opportunity to gain further conceptual ground by elevating human agency with this theoretical framework with the goal of better understanding how economic actors experience, relate to, and shape their institutional environment. Economic geographers certainly acknowledge the possibility for agency-centered institutional responses. Still, there is a tendency to present human agency as overt resistance to established institutional structures that are imposed upon them (see for example, Hatch, 2014)-where economic actors push back against a constraining rule or reject attempts to incentivize certain forms of behavior. This is certainly one possible source of institutional transformation. However, in isolation, this conceptualization overlooks the possibility that economic actors can also act through institutions in ways that may be much more creative, constructive, and collaborative.

To get us there, we believe it is useful to recognize institutions as lived experiences and with different categories of economic actors experiencing institutional life quite differently. The notion that institutions are lived experiences reflects insights from classical pragmatists, especially John Dewey and Hans Joas. Used more recently in the context of changing political systems (Berk \& Galvan, 2009), this framework emphasizes that human agency is more than "reified individual rationality;" instead "actors draw on a wide variety of cultural and institutional resources to create novel (institutional) combinations" (2009: 544). In this regard, institutions provide human actors with "the medium of creative action" for experimentation and improvisation (Berk \& Galvan, 2009; see also Sabel, 1996).

Building on work by Lester and Piore (2009), we add the concept of institutional interpretation. Rather than simply acting out a universal institutional script, economic agents interpret and reinterpret their institutional settings in ways that reflect and reinforce differences in interpretation. This implies that institutions can simultaneously coexist in multiple idiosyncratic states, reflecting a variety of interpretative frameworks through which economic actors engage with, and make sense of, their institutional surrounding. Moreover, economic actors do not just accept an existing institutional structure or requirement at face value. Attempts to make sense of institutions are not only an individual cognitive process (Weick, 1995) but also reflects larger historical and social context. Making sense of institutions is primed by social cues and edited through social feedback (Weber \& Glynn, 2006). Thus, institutional frameworks are interpretative and shifting.

Differences in institutional interpretation become especially relevant for studies of subnational economies. They also matter for processes of institutional change. An outsider coming into a region-or even an insider stepping into a new role within the region-might experience an existing institution very differently compared to someone who has 
been engaged in that space for a longer time. A newcomer might initially experience more formal elements of an institution, with a view that these are structures and regulations that are well-defined and mandated or imposed through top-heavy rules. Over time, however, there is a possibility for that same actor to reinterpret the institutional experience, recognizing deeper value and meaning. This reevaluation might eventually contribute to institutional internalization, whereby the relationship between that actor and institution evolves to become closer to an "enduring system of socially ingrained rules" (Hodgson, 2007:331).

Still, the reverse is also possible: An established practice or social exchange gets reified as a formal structure. In our own research, we have identified several instances where entrepreneurial actors take steps to formalize certain aspects of accepted practices and shared norms. As one example, a well-networked and highly regarded North Carolina-based attorney provided informal networking support to some of the state's earliest life sciences firms. In that capacity, he went well beyond his legal expertise to broker connections between entrepreneurial founders and outside investors and collaborators. He eventually worked with others in the state to formalize that role, creating the Council for Entrepreneurial Development in 1989, which continues to provide a variety of mentoring and networking initiatives. As this example helps to illustrate, institutional transformation is not linear or unidirectional-moving from formal to informal-but iterative and advancing in the reverse direction as well.

This institutional transience and the shifting interpretive frameworks it can come to reflect suggests that we need to look beyond standard oppositional dichotomies, like informal versus formal, especially if those categories are presented as fixed, predetermined or neatly bounded institutional characteristics. It suggests that we also need to avoid presenting institutions in the abstract and instead study them within their social and situational context: that is to say, in relation to the economic agents experiencing them and with the possibility for coexistence of varied interpretative lenses, leading to different experiences.

Building from this, we would also add that more standard institutional classifications inhibit a full appreciation of institutional change, especially the contribution of economic actors to institutional transformation. One source of institutional change involves reinterpretation-that is to say changes in perception from the reexamination of an institution through a different interpretative lens. But it can also involve collective acts that bring about more substantive and far-reaching changes-the creation of new structures and routines. Institutional transformation can result from attempts to reconcile or combine multiple interpretative frameworks, including those that might initially seem out of alignment or even in conflict. This is not simply a case of reconciling tensions between institutional rules and individual rational choice (Beckert, 1999). Rather, it can reflect competing institutional logics that act as a form of "productive friction" that support critical dialog and inspire collaboration and consensus building (Stark, 2011; see also Friedland \& Alford, 1991; Lester \& Piore, 2009). Endogenous institutional contradiction and ambivalence can therefore motivate entrepreneurial actors to engage in continual processes of collective reinterpretation.

\section{3 | INSTITUTIONS AND ORGANIZATIONS}

Extending this same logic, we see analytical value for studies of entrepreneurial development to move beyond recurring-often staid-debates over whether institutions are wholly distinct from organizations. While we agree that many "institutions cannot be reduced to specific organizations" (Storper, 1997: 268; see also Rodríguez-Pose, 2013), we do think that organizations still play an important and enduring role in understanding institutions. Mukherjee (2016: 10) quoting Wallace Stevens writes, "in the sum of the parts, there are only the parts," and notes that, "(Stevens) is referring to the deep structural mystery that runs through language: you can only decipher the meaning of a sentence by deciphering every individual word - yet a sentence carries more meaning than any of the individual words." Extending this logic, we can more tangibly understand institutions by examining organizations as related units within the larger form of regional institutions. Culture and norms that define institutional environments are nebulous and difficult to quantify, but they find material expression in organizations' programs, policies, and observable activities. This raises the possibility for studying the multiple roles that organizations play 
in supporting entrepreneurial development by extending opportunities for institutional engagement and reinterpretation.

In some cases, organizations can function as a protective institutional space-an integrating space where groups of related actors come together to work through and align different institutional interpretations and experiences. But equally an organization can also provide economic actors with a nuanced vantage point, where their affiliation with a particular organization or network of organizations can inform their interpretation of more encompassing or enveloping institutions, including those that might initially seem out of step with the patterns, routines, and norms within that organizational life. In this regard, the organizational setting becomes an interstitial space for institutional interpretation by, and among, economic actors. There is also a third possibility that organizations are economic actors in their own right, acting within an institutional setting and experimenting and improvising in creative ways that subsequently redefine the institutional environment.

A useful example from our work on entrepreneurial communities is venture capital-an institution that is comprised of multiple investor organizations. In our study region in Raleigh-Durham, venture capital-as encompassing institution-is often presented as underdeveloped and weakly capitalized and thus presumed a barrier to regional entrepreneurial success. But to lump all venture capital firms in our region together misses rich organizational heterogeneity that can itself be a source of entrepreneurial variation, as well as a resource for further institutional change. The region is home to a growing community of investors and venture capitalists that are pushing entrepreneurial firms to embrace sustainability and diversity goals. In recent years, they have positioned themselves as host organizations for national investor networks in support of sustainability and social entrepreneurship, thus deepening their influence within the region and also beyond its boundaries. Other venture capital firms have devised innovative strategies to connect local entrepreneurship to sources of financing outside the region, acting as brokers and matchmakers, in turn helping to stimulate interest among local investors. If we simply lumped together local venture capital as one unifying institution, we would miss the experimental nature of these strategies and the creative actions they represent and inspire. This also raises questions about generic recommendations for regions to emulate standard private equity models of venture capital, advising them instead to encourage organizations that are invested in the local region to engage with the entrepreneurial community in novel ways that are more appropriate to regional circumstances and opportunities.

It is also our observation that some organizations in pursuit of their own objectives can be the primary or leading source of institutional change. Norms and expectations, especially at the local level, can evolve through the experimentation that occurs within organizations. Once tested and perceived as viable, the practice may extend beyond the organization to become widespread and institutionalized. For example, the North Carolina Biotechnology Center, a state-funded economic development agency launched in 1981, experimented with different organizational models and routines in an effort to ensure legislative support (Feldman \& Lowe, 2011; Lowe \& Feldman, 2015). The results of this initial experimentation created expectations that have governed subsequent sector-specific support organizations in the region and buffered them against political attacks.

\section{4 | A LENS ONTO INSTITUTIONAL LIFE}

How can economic geographers document the institutional life of entrepreneurs? A key step involves looking at institutions from multiple vantage points-not assuming we know in advance how those institutions are experienced by economic actors or organizations simply because we can observe or document their existence. Rather, we need to ask direct, inquiring, and retrospective questions of those actors themselves in order to better gauge how institutions have been understood, interpreted, and even challenged within an entrepreneurial community and over time. This also implies the need for more robust methodologies that combine multiple data sources in order to better contextualize the complex and evolving relationship between economic actors and regional institutions, including recognizing differences in institutional interpretation that might lead some groups of entrepreneurs to underreport the level and extent 
of institutional influence and engagement. More than just a methodological challenge, however, differences in institutional interpretation also pose an opportunity to inform policy intervention through creative and collective action.

We provide an illustrative example from our ongoing research on entrepreneurial development in North Carolina's Research Triangle. Since 2008, we have collected detailed information on a near universe of life science entrepreneurial establishments founded in this region between 1960 and 2012 (Feldman \& Lowe, 2015). We include detailed information on the connections they have to a variety of organizations and institutions in the region, including research universities, industry associations, business development and technical assistance providers, economic development agencies, and financial investment firms. For each entrepreneurial establishment, we know who provided financial and institutional support, in what year and at what level. We also include details on the educational and career histories of founding entrepreneurs and entrepreneurial teams, which we capture through a review of personal biographies and work histories posted online or through social media sites. This allows us to trace entrepreneurial heritage, including whether firms were started by individuals with prior employment experience at one of several large pharmaceutical anchor corporations, with GlaxoSmithKline being especially prominent in our region. We also know which founders are most closely connected to our regional research universities, but equally are able to identify hybrid organizations with blends of founders from academic and corporate worlds with some teams involving nonlocals that moved into the region to help launch the firm. Finally, we include a wide range of performance measures for each firm related to innovation, sales, employment growth, major milestones, liquidity events, and changes in ownership.

In many respects, the data collection effort we have described thus far privileges formal institutional affiliations and supports within our region of study. Our methodology could therefore be viewed as an extension to an already familiar approach of regional innovation systems designed to map a region's "institutional infrastructure" (Braczyk \& Heidenreich, 1998; Lundvall, 2010). But by connecting individual firms and founders to that formal infrastructure and time-stamping each institutional support over the course of the firm's known lifespan, we capture more than an institutional snapshot: We create a dynamic resource for tracing and retracing the diverse and divergent navigation routes that entrepreneurs follow-that is to say, the specific chronology of their formal institutional life and the unique and intersecting pathways they use to traverse and engage with the region's evolving institutional landscape. With these data, we also have a starting place for learning more about differences in institutional interpretation and action.

To contextualize and learn from varying institutional experiences, we add a further methodological step: connecting directly with entrepreneurial founders themselves via in-depth interviews and structured focus groups or salons. We find that entrepreneurial actors move through and experience the same institutional environment quite differently. Some of this variation is shaped by earlier institutional experience, such as whether the firm has spun out of a regional university or is spawned by a large anchor corporation. The diverse mix of founding partners within the firm and the kinds of prior experiences each team member brings to the table when colaunching a new venture contributes additional complexity to the institutional experience. Our research suggests the particular institutional sequences that entrepreneurs follow are shaped by earlier experiences and organizational legacies, which can privilege certain connections, networks, and resources. But they can also reflect internal interpretative processes whereby actors from different backgrounds and with differing perspectives collectively interpret and act upon a diverse range of options and opportunities. We also find instances where institutional pathways reflect the particular position of the firms with respect to market orientation, technological specialization, or value chain status. As this suggests, it is difficult to determine in advance which specific elements of a region's institutional environment become more or less relevant and at what point in time they exert influence. Factors associated with new firm formation and scaling can certainly influence which institutional pathway is followed, but they are not predetermined nor fixed in time, but dynamic, opportunistic, and adaptive.

Our approach enables us to capture the broad array of institutional supports that scaffold a diversity of regional economic actors and with different levels of intensity over time (Feldman \& Lanahan, 2015; Lowe \& Gertler, 2009; Zoller, 2010). We suspect that this diversity of institutional experiences, as opposed to the dominance of one institutional pathway, encourages individuals to take different roles, allowing them to be active participants in shaping 
and reshaping institutional life. This participation is not limited to the act of simply knitting together varying institutional supports and thus contributing to processes of what some have described as institutional "thickening" (Amin \& Thrift, 1995; Martin, 2000). Entrepreneurs can also deepen their connections to specific institutions over time, eventually taking on influential roles such as board member, program advisor, entrepreneurial mentor, or policy expert. This suggests a constitutive dimension to institutional life, meaning that "as (they) continue to behave under a certain set of institutions, (they) begin to internalize the values embodied in those institutions, and as a result to change" (Chang and Evans 2005:103, parentheses added). But we believe this is not merely a case of internalization of existing institutional values and norms. We also find evidence of active institutional integration. This includes attempts by entrepreneurs to promote and extend opportunities to others, including future entrepreneurs, by working through some of the frictions or unexplored connections they encounter between formal institutions and shared norms, traditions, and informal networks. Essentially, this involves a process of eking out additional social and economic gains by working through institutional conflicts and "complementarities" in society (formal structures) and community (informal exchanges) (Rodríguez-Pose \& Storper, 2006).

Through our interviews, we also discovered that some entrepreneurs initially understated the full range of assistance they received from various regional institutions and support organizations. This finding reinforces the value of data triangulation methods for capturing a more complete institutional story, but it also suggests an additional data point for exploring aspects of institutional life. Admittedly, entrepreneurs did eventually remember receiving earlier institutional support once prompted with our more complete list of types of institutional assistance-in essence, the list functioned as an important triggering device spurring them to better reflect on their meandering institutional journey. That said, some also acknowledged they now associate those institutional connections-and notable individuals within them-as elements of an enduring professional and social network and as much more than a fixed resource for financing or for business development. In this regard, lapses in memory can reflect changes in institutional interpretation where economic actors begin to experience formal elements of institutional life in more fluid and informal ways, capturing additional value for themselves and their entrepreneurial ventures.

\section{5 | INSTITUTIONAL AGENCY AND POWER}

In conceptualizing institutions as lived experiences, we also want to emphasize the role of institutions as a creative medium for collective action (Berk \& Galvan, 2009)-as a resource for mobilizing groups of economic and institutional actors to bring about change to established routines and power structures. What might this mean for economic geographers interested in studying the development of entrepreneurial regions? In this context, an innovative entrepreneurial region can be presented as a geographic space for bringing together individuals with different institutional interpretations-a space that builds power by encouraging the intersection of multiple institutional lives and thus contributes material for creative activities and action. Molotch, Freudenburg, and Paulsen (2000) propose that within places "people know what to do, and in so doing, give identity to cities and regions ... places make themselves up ... The resulting stabilities are neither preordained nor frozen in content. A kind of rolling inertia allows for continuous flux within a stable mode of operation." This suggests thinking of institutional action as more than a means to accrue economic wealth, but also as a resource for building a unique regional and entrepreneurial identity.

We end this essay with an illustrative example from our own research, noting that technology entrepreneurs in our metropolitan region of North Carolina have tended to stay out of state politics, keeping their heads down and focusing on the daily grind of refining a complex technology while also building a business. But in the wake of the now infamous House Bill 2-enacted into law in August 2016 by conservative legislators in North Carolina-we are seeing evidence of behavioral change. The effects of this enacted bill are widespread, removing legal protections for workers, restricting local government from setting living wages, and curtailing other attempts to regulate business. 
But the most publicized aspect involves restrictions on public bathroom use, requiring individuals to only use facilities that align with their "biological sex" as specified on their birth certificate. This legislative action has direct and potentially dire consequences for North Carolina's transgender community, not only increasing risk of physical attacks but adding emotional stress with further social alienation. It also has detrimental economic effects, recently illustrated by the joint announcements of the Atlantic Coast Conference and the National Collegiate Athletic Association to pull all championship games and events from North Carolina, costing the various cities that had planned to host those events millions in revenue dollars.

Response by "tech" entrepreneurs has been swift and noteworthy, with many individuals speaking out publicly against the bill and expressing their support for North Carolina's lesbian, gay, bisexual, trans, and queer community (LGBTQ). For our purposes, an equally important response involves building political power within and through their affiliated institutions. In the recent past, many entrepreneurial support institutions in our region offered a political buffer: a protective sheath that enabled tech entrepreneurs to maintain distance from more conservative political forces and perspectives. Today, however, we find numerous and growing examples where entrepreneurial actors are intentionally breaking through that protective barrier, using their position within those institutions to strengthen their collective voice. In this capacity, they have reclaimed entrepreneurial spaces, including making a quick switch after a scheduled speaker canceled in opposition to the passage of House Bill 2. This action transformed what was initially meant to be a speaker-led inspirational talk on effective marketing and branding into a highly charged conversational space for collective reinterpretation and from which to inspire and motivate political action. Many involved in this ongoing conversation have subsequently used their influence within entrepreneurial support institutions-including their advisory role-to push out official statements and press releases expressing firm opposition to the bill. They have combined their technology know-how to create a virtual platform for posting passionate testimonials and gathering signatures in support of legislative repeal.

In sharing this additional detail, we are not saying they are leading the political charge against the bill; after all, our region has a rich and active network of worker and civil rights organizations-with powerhouse organizations like Equality NC and the NAACP at the helm-that have been mounting a powerful challenge to House Bill 2 and other "mean-spirited" legislative actions that have preceded it in recent years, from cutting Medicare and defunding public education to suppressing voting rights and enacting regressive tax policy. Our argument in this illustration is that in taking a more political and active stance and aligning with political groups, technology entrepreneurs are adding additional power to a growing opposition movement and they are doing so by forging connections across their varied institutional lives. There is legitimate concern that the current political environment in North Carolina will undermine the state's entrepreneurial future, encouraging mass exodus. But we conclude on a more positive note: that these recent actions by entrepreneurs could motivate staying power, providing a shared resource for building a more meaningful and rewarding entrepreneurial life through shared institutional interpretations, experiences, and collective action.

\section{ACKNOWLEDGEMENTS}

We received generous support for our research from the UNC Office of Economic and Business Development and the Odum Institute for Social Science Research, as well as the National Science Foundation and the Kauffman Foundation. We also wish to acknowledge the creative contribution and forensic skills of our UNC undergraduate and graduate research team.

\section{REFERENCES}

Amin, A., \& Thrift, N. (1995). Globalisation, institutional thickness and the local economy. In P. Healey, S. Cameron, S. Davoudi, S. Graham, \& A. Madani-Pour (Eds.), Managing cities: The new urban context (pp. 91-108). Chichester: Wiley.

Auerswald, P. (2015). Enabling Entrepreneurial Ecosystems. In D. Audretsch, A. Link, \& M. L. Walsok (Eds.), The Oxford handbook of local competitiveness (pp. 54-83). Oxford: Oxford University Press.

Bathelt, H., \& Glückler, J. (2013). Institutional change in economic geography. Progress in Human Geography, 38, 340-363. 
Beckert, J. (1999). Agency, entrepreneurs, and institutional change. The role of strategic choice and institutionalized practices in organizations. Organization Studies, 20(5), 777-799.

Bell-Masterson, J., \& Stangler, D. (2015). Measuring an entrepreneurial ecosystem. Arlington, Virginia: Kauffman Foundation.

Berk, G., \& Galvan, D. (2009). How people experience and change institutions: A field guide to creative syncretism. Theory and Society, 38(6), 543-580.

Braczyk, H. J., \& Heidenreich, M. (1998). Regional governance structures in a globalized world. In H. J. Braczyk, P. Cooke, \& M. Heidenreich (Eds.), Regional innovation systems: The role of governances in a globalized world (pp. 414-440). London: Routledge.

Chang, H. J. (2003). Globalization, economic development and the role of the state. London: Zed Books.

Chang, H. J., \& Evans, P. (2005). The Role of Institutions in Economic Change. In G. Dymski \& S. Da Paula (Eds.), Reimagining Growth (pp. 99-129). London: Zed Press.

Feldman, M. P., \& Braunerhjelm, P. (2006). The genesis of industrial clusters. In M. P. Feldman, \& P. Braunerhjelm (Eds.), Cluster genesis: Technology-based industrial development (pp. 1-13). Oxford, UK: Oxford University Press.

Feldman, M. P., \& Francis, J. (2002). The entrepreneurial spark: Individual agents and the formation of innovative clusters. In A. Q. Curzio, \& M. Fortis (Eds.), Complexity and industrial clusters (pp. 195-212). New York: Physica-Verlag.

Feldman, M. P., \& Lanahan, L. (2015). Crafting a Comeback: Innovation and Entrepreneurship as an Economic Development Strategy in Mature Regions. In: J. Bryson J. Clark V. Vanchan (Eds.), Handbook of manufacturing industries in the world economy (pp. 451-473). Cheltenham: Edward Elgar.

Feldman, M. P., \& Lowe, N. (2011). Restructuring for resilience: The importance of organizational design. Innovations Journal (MIT), 6(1), 129-146.

Feldman, M. P., \& Lowe, N. (2015). Triangulating regional economies: Realizing the promise of digital data. Research Policy, 44 (9), 1785-1793.

Feldman, M. P., Francis, J., \& Bercovitz, J. (2005). Creating a cluster while building a firm: Entrepreneurs and the formation of innovative clusters. Regional Studies, 39, 129-142.

Friedland, R., \& Alford, R. R. (1991). Bringing society back in: Symbols, practices and institutional contradictions. In W. Powell, \& P. DiMaggio (Eds.), The new institutionalism in organizational analysis (pp. 232-263). Chicago: University of Chicago Press.

Gertler, M. S. (2003). Tacit knowledge and the economic geography of context, or the undefinable tacitness of being (there). Journal of Economic Geography, 3(1), 75-99.

Hatch, C. J. (2014). Geographies of production: The institutional foundations of a design-intensive manufacturing strategy. Geography Compass, 8(9), 677-689.

Hodgson, G. M. (2007). The revival of Veblenian institutional economics. Journal of economic issues, 40(2), 324-340.

Lester, R. K., \& Piore, M. J. (2009). Innovation-The missing dimension. Cambridge, Massachusetts: Harvard University Press.

Lowe, N. J. (2009). Challenging tradition: Unlocking new paths to regional industrial upgrading. Environment and Planning $A$, 41(1), 128-145.

Lowe, N. J., and Feldman, M. P. (2015) Breaking the waves: Innovating at the intersections of local economic development planning. AAG. Chicago, Illinois, April 2015. Conference Paper.

Lowe, N. J., \& Gertler, M. S. (2009). Building on diversity: Institutional foundations of hybrid strategies in Toronto's life sciences complex. Regional Studies, 43(4), 589-603.

Lundvall, B. A. (Ed) (2010). National systems of innovation: Toward a theory of innovation and interactive learning (Vol. 2). London: Anthem Press.

Mack, E., \& Mayer, H. (2015). The evolutionary dynamics of entrepreneurial ecosystems. Urban Studies, 53(10), 2118-2133.

Malecki, E. J. (2009). Geographical environments for entrepreneurship. International Journal of Entrepreneurship and Small Business, 7, 175-190.

Martin, R. (2000). Institutional approaches in economic geography. In E. Sheppard, \& T. J. Barnes (Eds.), A companion to economic geography (pp. 77-94). Oxford, UK: Blackwell.

Mason, C., \& Brown, R. (2014). Entrepreneurial ecosystems and growth oriented entrepreneurship. Paris, January: Final Report to OECD.

Molotch, H., Freudenburg, W., \& Paulsen, K. E. (2000). History repeats itself, but how? City character, urban tradition, and the accomplishment of place. American Sociological Review, 65(6), 791-782.

Motoyama, Y., \& Knowlton, K. (2016). From resource munificence to ecosystem integration: The case of government sponsorship in St. Louis. Entrepreneurship \& Regional Development, 28(5-6), 448-470. 
Mukherjee, S. (2016). The gene: An intimate history. New York: Scribner.

Nelson, R. R. (1995). Recent evolutionary theorizing about economic change. Journal of Economic Literature, 33(1), 48-90.

North, D. C. (1990). Institutions, institutional change and economic performance. Cambridge, UK: Cambridge University Press.

Rodríguez-Pose, A. (2013). Do institutions matter for regional development? Regional Studies, 47(7), 1034-1047.

Rodríguez-Pose, A., \& Storper, M. (2006). Better rules or stronger communities? On the social foundations of institutional change and its economic effects. Economic Geography, 82(1), 1-25.

Sabel, C. F. (1996). Learning by Monitoring: The Dilemmas of Regional Economic Policy in Europe. In Organisation for economic co-operation and development (pp. 23-51). Networks of Enterprises and Local Development. Paris: OECD.

Sine, W. D., \& David, R. J. (2010). Institutions and entrepreneurship. Research in the Sociology of Work, 21, 1-26.

Spigel, B. (2015). "The relational organization of entrepreneurial ecosystems." Entrepreneurship Theory and Practice.

Stam, E. (2015). Entrepreneurial ecosystems and regional policy: A sympathetic critique. European Planning Studies, 23(9), 1759-1769.

Stark, D. (2011). The sense of dissonance: Accounts of worth in economic life. Princeton, NJ: Princeton University Press.

Storper, M. (1997). The regional world: Territorial development in a global economy. New York: Guildford.

Weber, K., \& Glynn, M. A. (2006). Making sense with institutions: Context, thought and action in Karl Weick's theory. Organization Studies, 27, 1639-1660.

Weick, K. E. (1995). Sensemaking in organizations. Thousand Oaks, CA: Sage.

Zoller, T. (2010). The Dealmaker Milieu: the Anatomy of Social Capital in Entrepreneurial Economies. In Unpublished PhD dissertation). Department of City and Regional Planning: University of North Carolina at Chapel Hill.

How to cite this article: Lowe NJ, Feldman MP. Institutional life within an entrepreneurial region. Geography Compass. 2017;11:e12306. https://doi.org/10.1111/gec3.12306 